\title{
Attitudes to Ethical Approach to Migration
}

V. Littva (Vladimir Littva)', A. Kralova (Anna Kralova)1,3, M. Sichman (Marek Sichman)', L. Kober (Lukas Kober)'1, I. Andrasi (Imrich Andrasi)1,2

${ }^{1}$ Faculty of Health, CU Ruzomberok, SK

${ }^{2}$ PhD. student, St. Elizabeth University, Bratislava, SK

${ }^{3}$ Central Military Hospital - Faculty Hospital Ruzomberok, SK

\section{E-mail address:}

littva.vladimir@gmail.com

\section{Reprint address:}

Vladimir Littva

Faculty of Health, CU Ruzomberok

Nam A. Hlinku 48

03401 Ruzomberok

SK

Source: Clinical Social Work and Health Intervention

Volume: 9

Issue: 2

Pages: $58-69$

Cited references: 14

\section{Reviewers:}

Vlastimil Kozon

Allgemeines Krankenhaus - Medizinischer Universitätscampus, Vienna, AT

Steve Szydlowski

University of Scranton, Department of Health Administration and Human Resources, USA

\section{Key words:}

Migration. Ethics. Economic Background. Religion Background. Cultural Background. Health Care Needs. Apprehensions.

\section{Publisher:}

International Society of Applied Preventive Medicine i-gap

CSWHI 2018; 9(2): 58 - 69; DOI 10.22359/cswhi_9_2_09 ( 2018 Clinical Social Work and Health Intervention

\section{Abstract:}

Objective: The aim of our research was to explore attitudes of Slovak citizens toward migrants in correlation between age, income per year, education and residency on one site and attitudes to economic background, religion, culture, Health Care needs and apprehensions related 
to migrants on another site. This creates an ethical framework of attitudes towards migrants and migration.

Design: Project study. The study was carried out under the KEGA project 007KU-4/2018 on Ethics in Public Health and Paramedics.

Participants: 352 respondents (179 men and 173 women). In terms of age: the majority, $188(53.4 \%)$ were of middle productive age; 104 were $<26$ year old; 60 were 55+. Regarding the education level: 110 respondents had graduated from a professional high school; 200 respondents had a University Education; 42 had a basic education. The high incidence of people with a University Education is influenced by requirements on the labor market in Slovakia. Regarding net income per year, $67.4 \%$ of respondents were at the $<12,000$ Euro per year level. Methods: A 27 items questionnaire MIETAT (Migration Ethics Attitudes) analyzed by descriptive characteristic for variables and subsequent testing of normality. Data were evaluated the correlation by using SPSS 22 Parametric Pearson Correlation Coefficient with a significance level of $\mathrm{p}<0.01$ and $\mathrm{p}<0.05$. High importance in evaluation is given to overall mean as well as means in individual domains.

Results: We evaluated the intrinsic reliability of the questionnaire using the Cronbach Alpha and Coefficient for MIETAT - Migration Ethics Attitude is 0.950 in the whole set, which we interpret as a high degree of elemental credibility, respectively internal consistency of the questionnaire. Mean was 3.680; Range 1.955; Variance 0.342. Value of achieved overall mean score 3,680 which means that our respondents in the rating scale have confirmed the maintenance of ethical principles in approaching to migrants in general.

Conclusion: The project study shows an important role in the ethical approach toward migrants and their needs. Every epoch of human history brings new challenges and urgently needs to respond in accordance with international rules and ethics. It's not easy, but we cannot avoid it. It may need a number of discussions, proposals, but the reality will require solutions based on a realistic assessment of the current situation. We are obliged to help and act in terms of fulfilling the mission we have in our life. Comprehensive altruistic education in ethical principles at schools can help fulfill this role.

\section{Introduction and Aim}

In recent decades, migration flow has been visible in many countries of the world. More and more often, we have been confronted with refugees fleeing war, turmoil and persecution. The current trend indicate the increase of migratory waves both nationally and cross-border. In the last five years, the European Union has been experiencing, a greater increase in the arrival of refugees in its territory. So far, in advanced countries, we meet with multi-culturalism which peacefully integrates migrants with majority domestic populations, but not in all countries.

The European Union has taken measures to mitigate the flow of migrants into their territories. European leaders have pressed 
on several fronts to stem migration after a burst in 2015 of more than a million asylum seekers. Afterward, European Union leaders struck a $\$ 7.1$ billion deal with Turkey to seal its borders and stanch the flow. They also started to work intensively in sub-Saharan Africa tying development aid to countries' willingness to accept returnees from Europe and offering fresh assistance in exchange for pledges to cut flows (Birnbaum, 2017). After some months, we see partial success from these measures. According to a quarterly overview regarding migration flows to Europe in 2017, the total number of arrivals to Europe by the end of March 2017 has been recorded as 30,465 with more than 29,000 counted as sea arrivals to Greece, Italy and Spain. This is in stark contrast to the 175,056 arrivals recorded in the same period in 2016. In the first three months of 2017, Greek Authorities reported 4,407 arrivals compared to the 152,617 recorded in the first quarter of 2016, a $97 \%$ decrease. Contrary to that, Italy is seeing an increase in arrivals since 2015 reaching a peak at the end of March 2017 with a total of 24,292 migrants registered as of 31 March 2017 (The UN Migration Agency, 2017). It is only obvious that with the advent of the mass waves of refugees often uncontrollable - questions arose about their legal status and, consequently, about their rights and obligations. Authors of an article entitled "Challenges in the provision of Health Care services for migrants: a systematic review through providers 'lens", discuss two important areas regarding Health Care for migrants:

- Classify migrants into groups by status. It then implies the obligations of individuals, as well as organizations, providers and countries vis-à-vis migrants.

- Recognizing interactions within the model of Health Care developed by Ferlie and Shortel (Suphanchaimat et al. 2015; Ferlie \& Shortel, 2001).
Suggested groups are:

- Legitimate migrants: all have the necessary resettlement papers and procedures performed in advance. From the point of view of providing Health Care they do not pose a risk and there is little ethical dilemma in Health Care provision.

- Illegal migrants: entering the territory of a foreign state without complying with procedures and necessary documents unregistered.

- Irregular illegal migrants: people who do not take steps to meet the legal conditions for entering the country and obtaining residency. They often change their place of residence to avoid official authorities. They do not contribute to the tax and insurance system but, in cases of need, they want to receive Health Care.

- Illegal undocumented and unregistered migrants: unregistered third-country migrants who usually cross the country and their stay is temporary.

- Involuntary displaced persons: any people born abroad who have entered the territory of the country because they were resettled under threat and have a justified fear of persecution; or possibly expelled for deportation after punishment.

- Refugees: any person who has left the country because of insufficient protection and is being persecuted or threatened with persecution because of race, religion, nationality, belonging to a social group, and/or political views.

- Asylum seekers: persons granted asylum (protection) who have the right to stay in the country. They first entered the territory of another country - usually as visitors, tourists, and then subsequently signed up for refugee status. (Biswas, 2001; Walker \& Barnett, 2007).

In the EU, most Health Care providers are currently focusing on mental health; infectious diseases; sexually transmitted 
diseases; reproductive health in migrants (Gray \& Ginneken, 2012). Some countries provide migrants with access only to emergency Health Care. These include Slovakia and other Central European countries. Others provide access to expanded services or full access to Health Care (Health Care in Nowhereland: Improving Services for Undocumented Migrants in the EU, 2010). The right to health regardless of the legal status of individuals is recognized widely in the different legislative frameworks, both at international and national levels (Calduch, 2008).

Providing Health Care for migrants includes several aspects:

- Humanitarian Issues - Ethics: Under International Conventions, Society should provide assistance for the poor, vulnerable and threatened within its jurisdiction.

- Public Health Problem - Ethics: Public Health Workers are legally and ethically responsible for ensuring public health protection for the population in the area. Especially in the area of the spread of contagious diseases. Providing care for migrants benefits the whole society.

- Do not give cause for attraction - reason for migration. One of the criticisms is the fact that the provision of services attracts more migrants - especially economic migrants.

- Another problem is the provision of services to those who do not contribute to the system. Why should others pay for them? This could affect the provision of care for taxpayers.

Yet it is still unclear how migration should be regulated to be fair to the sending societies, the host societies and the individual migrant (Straehle, 2018). The views of responsible politicians but also of the public differ. They are often unconventional and not helpful in solving the problems. For that reason the implications of the new regime of harsher migration and refugee policies are explored and viewed in historical context. Fear of terrorism is cited as the reason for current proposals for exclusion of migrants from Muslim-majority countries, but this fear is tainted by political manipulation and exaggeration (Healy, 2017).

The aim of our research was to find attitudes of Slovak citizens toward migrants in correlation between age, income per year, education and residency on one site and attitudes to economic background, religion, culture, Health Care needs and apprehensions related to migrants at another site. The study was carried out under the KEGA project 007KU-4/2018 on Ethics in Public Health and Paramedics.

The research sample consisted of a total of 352 respondents, of which 179 were men (50.9\%) and 173 were women (49.1\%). The average age of respondents was 44.49 years ( \pm 32.51 years). In terms of age majority was in middle productive age $188(53.4 \%)$; 104 were young people; 60 were $55+$. The largest group regarding education level was presented by 110 respondents graduated from a professional high school followed by 100 respondents with University Education at BSC Level. 100 respondents also achieved MS and $\mathrm{PhD}$. The high incidence of University Education is because of requirements in the labor market in Slovakia with pressure to increase education here has been very strong in recent decades. Many workers had to supplement their tertiary education to maintain their jobs even though it was not necessary before. A majority $(67.4 \%)$ of respondents regarding net income per year is in the level less than $12000 €$ per year. It corresponds with the economic conditions of the country where the average gross wage is less than $1000 €$. The distribution of the sample in terms of residence is proportional to distribution of 
the population in Slovakia. More detailed information about the research sample is in Table 1.
Questionnaire MIETAT consists of five demographic variables (gender, age, education, income per year and residency) and five assessment domains:

Table 1: Frequency table of categorical variables: gender, age, education, income per year, residency.

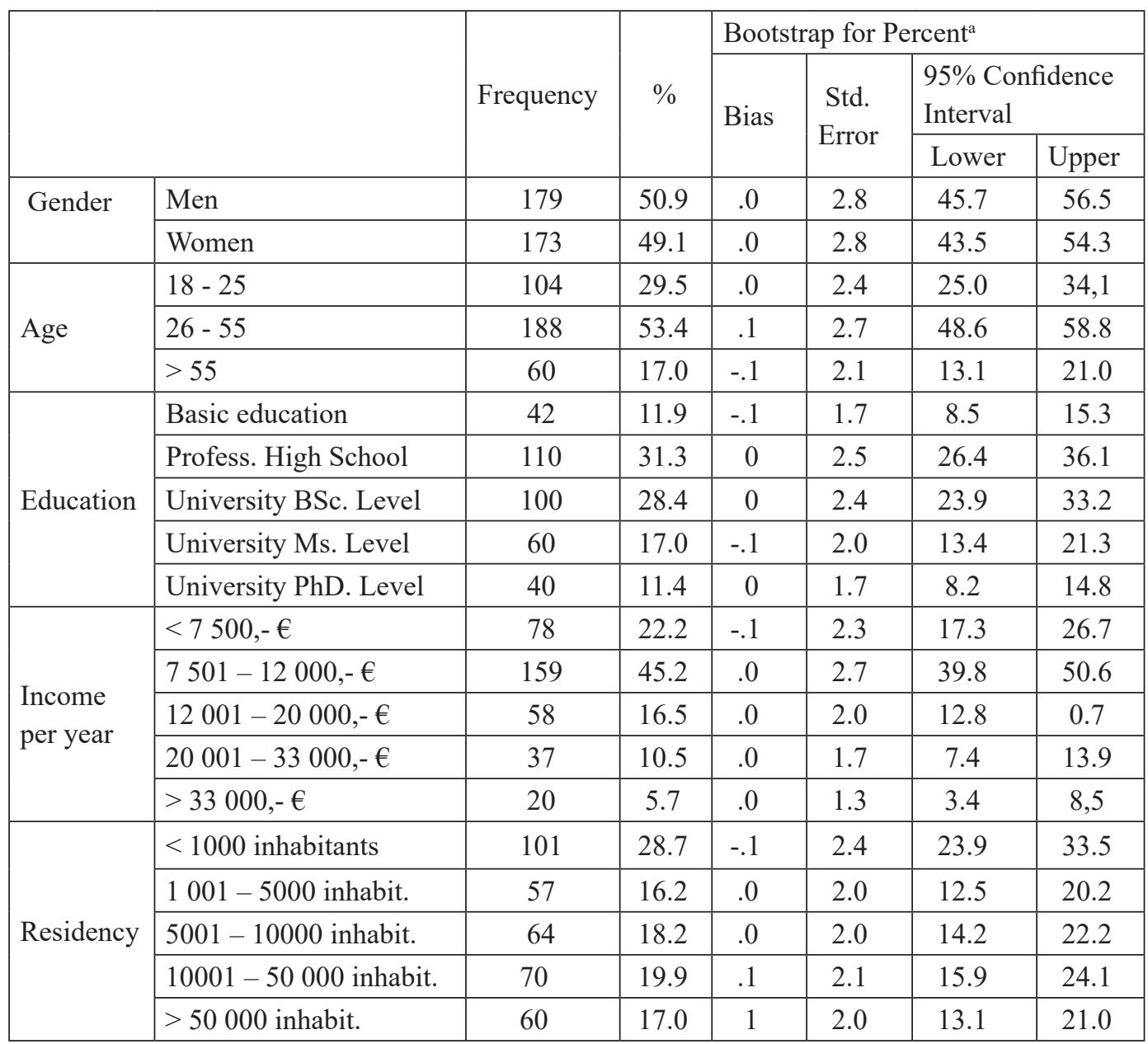

\section{Methods}

To obtain relevant data, we created a 27 item questionnaire MIETAT (Migration Ethics Attitudes) analyzed by descriptive characteristic for variables and subsequent testing of normality. Data were evaluated for the correlation by using SPSS 22 Parametric Pearson Correlation Coefficient with a significance level of $\mathrm{p}<0.01$ and $\mathrm{p}<0.05$.
Migration, ethics and economy;

Migration, ethics and religion;

Migration, ethics and culture;

Migration, ethics and Health Care;

Migration, ethics and Apprehensions.

These five domains give a comprehensive view of the ethical attitude of the respondents towards migrants. In each domain 
are 5 to 6 questions with the possibility of marking one correct answer. Answers are evaluated by Likert Scale from 1 to 5 . The higher the score achieved, the more ethical the approach from respondents is. We evaluated the questionnaire's reliability using Cronbach Alpha. The evaluation of the questionnaire is based on the determination of a mean in the whole questionnaire as well as individual domains and questions. The higher the score (maximum 5) achieved, the more ethical the respondents' approach to migrants is, and in accordance with internationally accepted standards. We've determined four levels of evaluation:

- Score 1,000 - 2,000 = Ethical approach with signs of negative attitude towards migrants and migration, which is marked by the violation of international documents and conventions.

- Score 2,001 - 3,000 = Poor ethical approach to migrants and migration with
- Score 4,001 - 5,000 = Strong ethical approach to migration and migration, including strong altruism and increased solidarity. International documents and conventions are not only observed, but rather positively exceeded.

\section{Results}

In our survey, we achieved the following results: characteristics for variables obtained through the MIETAT questionnaire (Migration Ethics Attitudes).

We evaluated the intrinsic reliability of MIETAT questionnaire using the Cronbach Alpha Coefficient. As can be seen in Table 2 , the value of the coefficient is 0.950 in the whole set, which we interpret as a high degree of elemental credibility, respectively internal consistency of the questionnaire. None of the 27 items reduces this value, so we consider the items to be consistently saturation to that sub-scale.

Table 2: Reliability Statistics.

\begin{tabular}{|l|c|c|c|}
\hline & $\begin{array}{l}\text { Cronbach's } \\
\text { Alpha }\end{array}$ & $\begin{array}{l}\text { Cronbach's Alpha Based } \\
\text { on Standardized Items }\end{array}$ & $\begin{array}{l}\text { No. of } \\
\text { Items }\end{array}$ \\
\hline Overall & .950 & .947 & 27 \\
\hline Domain 1 Migration, Ethics \& Economy & .869 & .872 & 6 \\
\hline Domain 2 Migration, Ethics \& Religion & .854 & .853 & 6 \\
\hline Domain 3 Migration, Ethics \& Culture & .786 & .763 & 5 \\
\hline Domain 4 Migration, Ethics \& Health Care & .582 & .614 & 5 \\
\hline Domain 5 Migration, Ethics \& Apprehensions & .821 & .830 & 5 \\
\hline
\end{tabular}

indications of possible change dependent on conditions. International documents and conventions are observed only under supervision and coercion.

- Score 3,001 - 4,000 = Ethically positive approach to migrants and migration, which carries signs of hesitation and occasional conditionality. International documents and conventions are observed.
During our research we achieved a mean score of 3,680 which means that our respondents in the rating scale have confirmed the maintenance of ethical principles in approaching immigrants in general. The best scores have been achieved in the Health Care domain 4,246 and the worst in the domain focused on the economic impact of 
migration 3,403. More detailed statistical information on the score achieved is in Tables 3 and 4 . achieve additivity must be minimum 3,286. Significant interaction means that the effect of factors on the dependent variable is

Table 3: Summary Item Statistics.

\begin{tabular}{|l|c|c|c|c|c|c|c|}
\hline & Mean & Minimum & Maximum & Range & $\begin{array}{l}\text { Maximum / } \\
\text { Minimum }\end{array}$ & Variance & $\begin{array}{l}\text { No. of } \\
\text { Items }\end{array}$ \\
\hline Item Means & 3,680 & 2,886 & 4,841 & 1,955 & 1,677 &, 342 & 27 \\
\hline Item Variances & 1,090 & .134 & 1,726 & 1,592 & 12,869 &, 203 & 27 \\
\hline $\begin{array}{l}\text { Inter-Item } \\
\text { Covariances }\end{array}$ &, 450 &,- 128 & 1,148 & 1,276 & $-8,942$ &, 082 & 27 \\
\hline $\begin{array}{l}\text { Inter-Item } \\
\text { Correlations }\end{array}$ &, 397 &,- 150 &, 761 &, 912 & $-5,059$ &, 041 & 27 \\
\hline
\end{tabular}

Concerning the economic burden and the impact on the ethical attitudes of the recipient country, we reached a score in our research sample of 3,403 . It presents an ethically positive approach to migrants and migration with some concerns. This is the situation when there is relatively high unemployment in the country compared to the surrounding countries and the standard of living is below the level of the surrounding countries.

In relation to the religion, it was higher 3,665 , but it differed significantly from one religion to another. Desirability and challenges of delivering Universal Health Care is predicated on a belief enshrined in international human rights agreements that it is morally fair that all individuals have "rights to health and to a standard of living adequate for health" (Braveman et all. 2011; Vissandjée et al. 2017).

Tukey's test of additivity assessed if the factor variables are additively related to the expected value of the response variable as seen in Table 5. In our case the test for non-additivity was statistically significant, the data are no additive because Mean Square was 1,416 and estimate power to non-additive, and the study of the main effects (separate factors) gets into the mood. Interaction is interpreted by comparing the diameters of individual cells.

Table 4: Summary Domains Statistics.

\begin{tabular}{|l|c|c|c|}
\hline & Mean & Std. Deviation & $\mathrm{N}$ \\
\hline $\begin{array}{l}\text { Migration } \\
\text { Ethics and } \\
\text { Economy }\end{array}$ & 3,403 & 1,1227 & 352 \\
\hline $\begin{array}{l}\text { Migration } \\
\text { Ethics and } \\
\text { Religion }\end{array}$ & 3,665 & 1,004 & 352 \\
\hline $\begin{array}{l}\text { Migration } \\
\text { Ethics and } \\
\text { Culture }\end{array}$ & 3,578 & 1,094 & 352 \\
\hline $\begin{array}{l}\text { Migration } \\
\text { Ethics and } \\
\text { Health Care }\end{array}$ & 4,246 & 0,742 & 352 \\
\hline $\begin{array}{l}\text { Migration } \\
\text { Ethics and } \\
\text { Apprehensions }\end{array}$ & 3,572 & 1,086 & 352 \\
\hline
\end{tabular}


Table 5: ANOVA with Tukey's Test for Non-additivity.

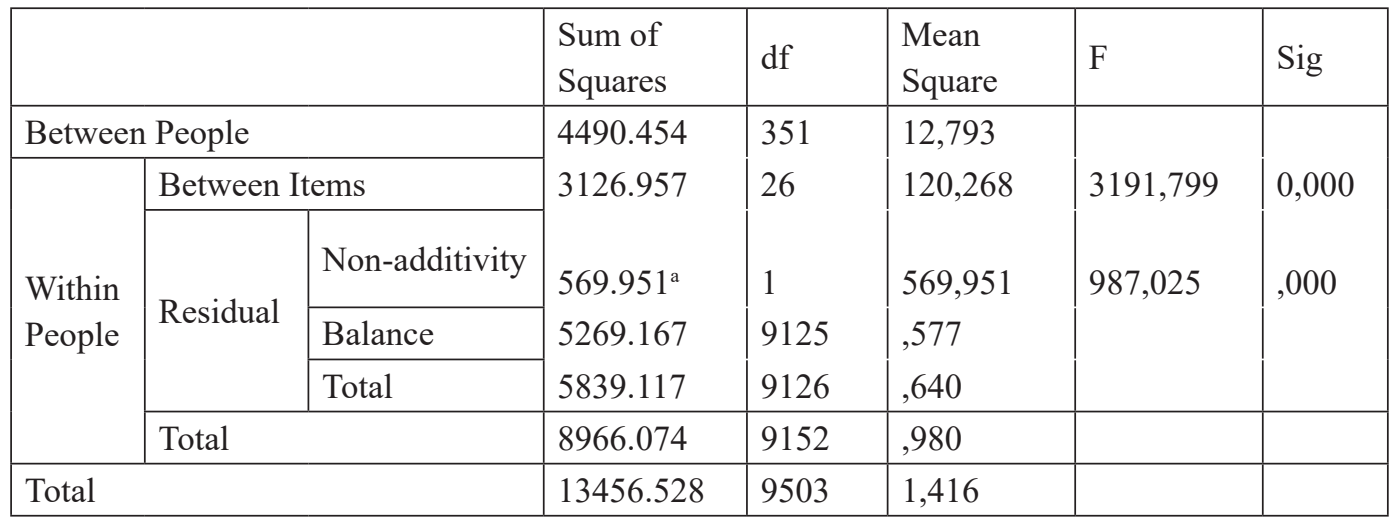

Grand Mean = 3,68

a. Tukey's estimate of power to which observations must be raised to achieve additivity $=3,286$.

Hotelling's t-squared statistic as a generalization of Student's t-statistic confirmed significance in multivariate distribution proportional to the F-distribution and distribution of a set of statistics which are natural generalizations of the statistics underlying Student's t-distribution. See Table 6.

Table 6: Hoteling's T-Squared Test.

\begin{tabular}{|c|c|c|c|c|}
\hline $\begin{array}{c}\text { Hotelling's } \\
\text { T-Squared }\end{array}$ & F & df1 & df2 & Sig \\
\hline 5371,040 & 191,865 & 26 & 326 &, 000 \\
\hline
\end{tabular}

Concerning the correlation of individual questions to gender, the significance of differences in male/female responses was confirmed at the level $\mathrm{p}<0.05$. The rationale is simple. Women show more compassion and greater solidarity to the needy than men. Significant correlation between age groups of respondents and individual questions was not confirmed in majority items. On the other side, correlations regarding individual questions toward education, income per year of respondents and residency have been confirmed in majority of items at the level $\mathrm{p}<0.05$.

Table 7: Correlations 27 Items.

\begin{tabular}{|c|c|c|c|c|c|c|}
\hline & & Sex & Age & Education & $\begin{array}{l}\text { Income } \\
\text { per year }\end{array}$ & Residency \\
\hline \multirow{2}{*}{$\begin{array}{l}\text { Domain 1: } \\
1 \text { Migrants and } \\
\text { new jobs }\end{array}$} & Pearson Correlation &,$- 258^{* *}$ &,- 014 &, $530^{* *}$ &, $609^{* *}$ &, $170^{* *}$ \\
\hline & Sig. (2-tailed) &, 000 & ,797 &, 000 &, 000 & ,001 \\
\hline \multirow{2}{*}{$\begin{array}{l}\text { Domain 1: } \\
2 \text { Amount of } \\
\text { Immigrants } \\
\text { Allowed }\end{array}$} & Pearson Correlation &,$- 198^{* *}$ & 074 &, $498^{* *}$ &, $413^{* *}$ &, $286^{* *}$ \\
\hline & Sig. (2-tailed) &, 000 &, 165 &, 000 &, 000 & ,000 \\
\hline \multirow{2}{*}{$\begin{array}{l}\text { Domain 1: } \\
3 \text { Economic } \\
\text { Background of } \\
\text { Migrants }\end{array}$} & Pearson Correlation &,$- 203^{* *}$ &, 017 &, $388^{* *}$ &, $307^{* *}$ &, $227^{* *}$ \\
\hline & Sig. (2-tailed) &, 000 &, 745 & ,000 &, 000 & ,000 \\
\hline
\end{tabular}




\begin{tabular}{|c|c|c|c|c|c|c|}
\hline \multirow{2}{*}{$\begin{array}{l}\text { Domain 1: } \\
4 \text { Education, Skill } \\
\text { or Qualification of } \\
\text { Migrants }\end{array}$} & Pearson Correlation &,$- 337^{* *}$ &, $198^{* *}$ &, $465^{* *}$ &, $362^{* *}$ &, $238^{* *}$ \\
\hline & Sig. (2-tailed) & ,000 & ,000 &, 000 & ,000 & ,000 \\
\hline \multirow{2}{*}{$\begin{array}{l}\text { Domain 1: } \\
5 \text { Taxes and } \\
\text { services }\end{array}$} & Pearson Correlation &,$- 456^{* *}$ &,- 032 &, $423^{* *}$ &, $302^{* *}$ & $316^{* *}$ \\
\hline & Sig. (2-tailed) &, 000 & ,546 &, 000 &, 000 &, 000 \\
\hline \multirow{2}{*}{$\begin{array}{l}\text { Domain 1: } \\
6 \text { Allowance for } \\
\text { specific professions }\end{array}$} & Pearson Correlation &,$- 220^{* *}$ & , 103 &, $569^{* *}$ &, $371^{* *}$ &, $377^{* *}$ \\
\hline & Sig. (2-tailed) &, 000 &, 054 & ,000 & ,000 &, 000 \\
\hline \multirow{2}{*}{$\begin{array}{l}\text { Domain 2: } \\
7 \text { Christian } \\
\text { background of } \\
\text { Migrants }\end{array}$} & Pearson Correlation &,$- 364^{* *}$ &,- 015 &, $520^{* *}$ &, $450^{* *}$ &, $215^{* *}$ \\
\hline & Sig. (2-tailed) & ,000 & ,786 & ,000 &, 000 & ,000 \\
\hline \multirow{2}{*}{$\begin{array}{l}\text { Domain 2: } \\
8 \text { Migrants } \\
\text { from Islamic } \\
\text { Background }\end{array}$} & Pearson Correlation &,$- 272^{* *}$ & $111^{*}$ &, $570^{* *}$ &, $466^{* *}$ &, $115^{*}$ \\
\hline & Sig. (2-tailed) &, 000 & ,038 & ,000 &, 000 & ,031 \\
\hline \multirow{2}{*}{$\begin{array}{l}\text { Domain 2: } \\
9 \text { Migrants } \\
\text { from Hinduist } \\
\text { Background }\end{array}$} & Pearson Correlation &,$- 295^{* *}$ &,- 055 &, $600^{* *}$ &, $525^{* *}$ &, $131^{*}$ \\
\hline & Sig. (2-tailed) &, 000 & ,303 &, 000 &, 000 & ,014 \\
\hline \multirow{2}{*}{$\begin{array}{l}\text { Domain 2: } \\
\text { 10 Migrants } \\
\text { from Buddhist } \\
\text { Background }\end{array}$} & Pearson Correlation &,$- 131^{*}$ & ,067 &, $467^{* *}$ &, $426^{* *}$ & , 101 \\
\hline & Sig. (2-tailed) &, 014 & ,208 &, 000 &, 000 &, 058 \\
\hline \multirow{2}{*}{$\begin{array}{l}\text { Domain 2: } \\
11 \text { Migrants } \\
\text { from Animistic } \\
\text { Background }\end{array}$} & Pearson Correlation &,$- 346^{* *}$ &,- 032 &, $628^{* *}$ &, $595^{* *}$ &, $265^{* *}$ \\
\hline & Sig. (2-tailed) &, 000 &, 547 &, 000 &, 000 & ,000 \\
\hline \multirow{2}{*}{$\begin{array}{l}\text { Domain 2: } \\
12 \text { Migrants from } \\
\text { Religion less } \\
\text { Background }\end{array}$} & Pearson Correlation &,$- 372^{* *}$ &,$- 208^{* *}$ &, $185^{* *}$ &, $367^{* *}$ &, $261^{* *}$ \\
\hline & Sig. (2-tailed) &, 000 &, 000 &, 000 &, 000 &, 000 \\
\hline \multirow{2}{*}{$\begin{array}{l}\text { Domain 3: } \\
13 \text { Requirements } \\
\text { to speak official } \\
\text { language }\end{array}$} & Pearson Correlation &,$- 309^{* *}$ &,$- 147^{* *}$ &, $487^{* *}$ &, $517^{* *}$ & , 105 \\
\hline & Sig. (2-tailed) &, 000 & ,006 &, 000 &, 000 & ,050 \\
\hline \multirow{2}{*}{$\begin{array}{l}\text { Domain 3: } \\
14 \text { Acceptation of } \\
\text { domestic culture }\end{array}$} & Pearson Correlation &,$- 291^{* *}$ &, 090 &, $434^{* *}$ &, $263^{* *}$ &, $205^{* *}$ \\
\hline & Sig. (2-tailed) &, 000 & ,092 & ,000 &, 000 &, 000 \\
\hline \multirow{2}{*}{$\begin{array}{l}\text { Domain 3: } \\
15 \text { Previous } \\
\text { traditions and } \\
\text { culture }\end{array}$} & Pearson Correlation &,$- 237^{* *}$ &, $313^{* *}$ &, $751^{* *}$ &, $477^{* *}$ &, $163^{* *}$ \\
\hline & Sig. (2-tailed) &, 000 &, 000 & ,000 &, 000 &, 002 \\
\hline
\end{tabular}




\begin{tabular}{|c|c|c|c|c|c|c|}
\hline \multirow{2}{*}{$\begin{array}{l}\text { Domain } 3 \text { : } \\
16 \text { Eating habits }\end{array}$} & Pearson Correlation & ,009 &,$- 223^{* *}$ & $230^{* *}$ & $316^{* *}$ &,$- 115^{*}$ \\
\hline & Sig. (2-tailed) & 860 & ,000 & ,000 & ,000 &, 032 \\
\hline \multirow{2}{*}{$\begin{array}{l}\text { Domain 3: } \\
17 \text { Interpersonal } \\
\text { relationships }\end{array}$} & Pearson Correlation &,$- 414^{* *}$ &,- 088 &, $527^{* *}$ &, $545^{* *}$ & ,288** \\
\hline & Sig. (2-tailed) &, 000 &, 100 & ,000 &, 000 & ,000 \\
\hline \multirow{2}{*}{$\begin{array}{l}\text { Domain } 4: \\
18 \text { Free equal } \\
\text { access to all Health } \\
\text { Care }\end{array}$} & Pearson Correlation &,$- 398^{* *}$ &,$- 193^{* *}$ & $493^{* *}$ &, $559^{* *}$ & $398^{* *}$ \\
\hline & Sig. (2-tailed) &, 000 & ,000 & ,000 & ,000 & ,000 \\
\hline \multirow{2}{*}{$\begin{array}{l}\text { Domain 4: } \\
19 \text { Free access } \\
\text { to life-saving } \\
\text { treatment }\end{array}$} & Pearson Correlation &, $125^{*}$ & ,008 &, $310^{* *}$ &, $144^{* *}$ &,$- 152^{* *}$ \\
\hline & Sig. (2-tailed) & ,019 & ,888 & ,000 & ,007 & ,004 \\
\hline \multirow{2}{*}{$\begin{array}{l}\text { Domain 4: } \\
20 \text { Access to paid } \\
\text { services }\end{array}$} & Pearson Correlation &,$- 318^{* *}$ &,$- 139^{* *}$ & $273^{* *}$ & $311^{* *}$ & ,021 \\
\hline & Sig. (2-tailed) &, 000 & ,009 & ,000 & ,000 & ,690 \\
\hline \multirow{2}{*}{$\begin{array}{l}\text { Domain 4: } \\
\text { Migration, Ethics } \\
\text { and Health Care } 21 \\
\text { Insurance }\end{array}$} & Pearson Correlation &,$- 274^{* *}$ &, $237^{* *}$ &, $382^{* *}$ & $196^{* *}$ &, 095 \\
\hline & Sig. (2-tailed) &, 000 &, 000 & ,000 &, 000 &, 075 \\
\hline \multirow{2}{*}{$\begin{array}{l}\text { Domain 4: } \\
22 \text { Prioritization of } \\
\text { domestic residents }\end{array}$} & Pearson Correlation &,$- 288^{* *}$ &,- 010 &, $373^{* *}$ & $298^{* *}$ &, $188^{* *}$ \\
\hline & Sig. (2-tailed) &, 000 & ,857 &, 000 &, 000 &, 000 \\
\hline \multirow{2}{*}{$\begin{array}{l}\text { Domain 5: } \\
23 \text { Possibility of } \\
\text { spreading new } \\
\text { diseases }\end{array}$} & Pearson Correlation &, 025 &, $157^{* *}$ &, $494^{* *}$ &, $618^{* *}$ &, $166^{* *}$ \\
\hline & Sig. (2-tailed) & ,644 & ,003 &, 000 &, 000 & ,002 \\
\hline \multirow{2}{*}{$\begin{array}{l}\text { Domain 5: } \\
24 \text { Possibility of } \\
\text { increased crime }\end{array}$} & Pearson Correlation &,$- 271^{* *}$ &,- 078 &, $644^{* *}$ &, $596^{* *}$ &, $295^{* *}$ \\
\hline & Sig. (2-tailed) &, 000 & , 146 &, 000 &, 000 &, 000 \\
\hline \multirow{2}{*}{$\begin{array}{l}\text { Domain 5: } \\
\text { 25 Possible } \\
\text { terrorist attacks }\end{array}$} & Pearson Correlation &,$- 147^{* *}$ &, $283^{* *}$ &, $628^{* *}$ &, $464^{* *}$ & ,066 \\
\hline & Sig. (2-tailed) & ,006 & ,000 & ,000 & ,000 & ,219 \\
\hline \multirow{2}{*}{$\begin{array}{l}\text { Domain 5: } \\
26 \text { Possibility } \\
\text { of decline in the } \\
\text { quality of life }\end{array}$} & Pearson Correlation &,$- 205^{* *}$ &,- 007 &, $515^{* *}$ &, $616^{* *}$ & $360^{* *}$ \\
\hline & Sig. (2-tailed) &, 000 & ,896 &, 000 &, 000 &, 000 \\
\hline \multirow{3}{*}{$\begin{array}{l}\text { Domain 5: } \\
27 \text { Impact on } \\
\text { political life }\end{array}$} & Pearson Correlation &,$- 132^{*}$ &,- 058 &, $429^{* *}$ &, $536^{* *}$ &, $279^{* *}$ \\
\hline & Sig. (2-tailed) &, 013 &, 274 & ,000 & ,000 &, 000 \\
\hline & $\mathrm{N}$ & 352 & 352 & 352 & 352 & 352 \\
\hline
\end{tabular}

**. Correlation is significant at the 0.01 level (2-tailed).

*. Correlation is significant at the 0.05 level (2-tailed). 


\section{Conclusion}

Every epoch of human history brings new challenges and is urgently needed to respond in accordance with international rules and ethics. It's not easy, but we cannot avoid it. It may be a number of discussions, proposals, but the reality will require solutions based on a realistic assessment of the current situation. We are obliged to help and act in terms of fulfilling the mission we have in our lives. Comprehensive education in ethical principles and altruistic education at schools can help fulfill this role. We are glad that we can say that the Slovak respondents reached a total score of 3,680, which means an ethically positive approach to migrants and migration with signs of hesitation and occasional conditionality. International documents and conventions are observed although we often hear criticism of the way in which migrants are distributed within the European Union.

\section{References}

1. BIRNBAUM M (2017) Could the flow of migrants to Europe be stopped? In: The Washington Post, October 3, 2017; [online]. [cit. 2018-01-10]. ISSN: 0190-8286. Available on the Internet: https://www. washingtonpost.com/world/europe/couldthe-flow-of-migrants-to-europe-be- stoppe d/2017/10/02/e76ac66e-a2ce-11e7-b5738 ec86cdfe1ed_story.html?utm_term $=$.fc$1 \mathrm{c} 42 \mathrm{c} 99 \mathrm{c}$ of

2. BISWAS D, KRISTIANSEN M, KRASNIK A et al. (2011) Access to Health Care and alternative health-seeking strategies among undocumented migrants in Denmark. In: BMC Public Health Vol.11; Nr.1; p. 560.

3. BRAVEMAN P (2011) Health disparities and health equity: The issue is justice. In: Am J Public Health. 2011;101(Suppliment 1): S149-55. doi: 10.2105/AJPH.2010.300062.

4. CALDUCH EN et al. (2008) Ethical and legal issues related to health access for migrant populations in the Euro - Mediterranean Area. In: EUROSURVEILLANCE Vol. 13Issue 50, ISSN 1025-496X.

5. GRAY BH, VAN GINNEKEN E (2012) Health Care for Undocumented Migrants: European Approaches, In: Issues in International Health Policy, Commonwealth Fund pub. 1650 Vol. 33, [online]. [cit. 2018-0110]. Available on the Internet: http://www. commonwealthfund.org/publications/issue-briefs/2012/dec/health-care-for-undocu mented-migrants.

6. FERLIE EB, SHORTELL SM (2001) Improving the quality of Health Care in the United Kingdom and the United States: a framework for change. In: The Milbank Quarterly 79(2):281-315. ISSN:0887-378X

7. GRIT K, DEN OTTER J J, SPREIJ A (2012) Access to Health Care for Undocumented Migrants: A Comparative Policy Analysis of England and the Netherlands In: Journal of Health Politics, Policy, and Law, 37 (1):37-67.

8. Health Care in Nowhereland: Improving Services for Undocumented Migrants in the E.U. (2010) Open Access, [online]. [cit. 2018-01-08]. The project's reports. Available on the Internet: http://www.nowhereland.info.

9. HEALY LM (2017) No Longer Welcome: Migration Policy and Challenges for Social Work. Affilia - Journal of Women and Social Work, 7, Vol. 32, Issue: 2, Pages: 247 - 250.

10. STRAEHLE C (2018) Justice in migration. Canadian Journal of Philosophy Volume: 48, Issue: 2, Pages: 245-265.

11. SUPHANCHAIMAT R et al. (2015) Challenges in the provision of Health Care services for migrants: a systematic review through providers' lens, In: BMC Health Services Research, DOI 10.1186/s12913015-1065-z, Open Access, [online]. [cit. 2018-01-10]. ISSN: 1472-6963, Available on the Internet: <http://bmchealthservres. biomedcentral.com/articles/10.1186/ s12913-015-1065-z > . 
12. THE UN MIGRATION AGENCY (2017) Migration Flows to Europe Quarterly Overview - March, 2017; [online]. [cit. 2018-0110]. Available on the Internet: http://migration.iom.int/docs/Q1 statistical overview. pdf.

13. VISSANDJÉE B, SHORT WE, BATES $\mathrm{K}$ (2017) Health and legal literacy for migrants: twinned strands woven in the cloth of social justice and the human right to Health
Care. BMC International Health and Human Rights, 17, 10. Open Access, [online]. [cit. 2018-01-10]. Available on the Internet: http://doi.org/10.1186/s12914-017-0117-3.

14. WALKER PF, BARNETT ED (2007) An introduction to the field of refugee and immigrant Health Care. In: Walker PF, Barnett ED, editors. Immigrant Medicine. 1st ed. Philadelphia: WB Saunders Co, 2007; 765 p. ISBN13: 978-0323034548. 